\title{
Saving the SDGs? \\ Strengthening Partnership for Achieving SDGs in the Post-Covid-19 Digital World ${ }^{1,2}$
}

\author{
M. Larionova
}

\begin{abstract}
Marina Larionova - PhD, Head, Centre for International Institutions Research (CIIR), Russian Presidential Academy of National Economy and Public Administration (RANEPA); Professor, Faculty of World Economy and International Affairs, National Research University Higher School of Economics; 11 Prechistenskaya naberezhnaya, Moscow, 119034, Russian Federation; E-mail: larionova-mv@ranepa.ru
\end{abstract}

\begin{abstract}
The 2020, intended to give a good start to the Decade of Action to achieve SDGs by the target date of 2030, became a year of unprecedented health, social and economic crisis. The COVID-19 pandemic plunged the world into the worst global recession since the Great Depression, reversed progress across the full range of the SDGs jeopardizing the Agenda 2030 implementation. To build back better it is vital to assess the COVID-19 pandemic impact on economic growth and sustainable development and reflect on how to reenergize partnerships for saving the SDGs. This article aims to assess the COVID-19 pandemic impact on economic growth and sustainable development and offer recommendations on international cooperation and partnerships for saving the SDGs. It article reviews estimates of the triple crisis toll on the goals implementation. It then looks at the key international institutions' initiatives to support developing countries in their response to the pandemic and associated economic shocks. The article concludes by outlining priorities for strengthening international cooperation on sustainable development which include incorporation of key components of digitalization into the SDGs as concrete targets and indicators and a comprehensive G20-led debt relief initiative providing for the released funds allocation to poverty and inequality eradication, health and education - related SDGS.
\end{abstract}

Key words: sustainable development goals; COVID-19 pandemic; UN; G20; international financial institutions; debt sustainability; human development; digitalization; comprehensive debt relief initiative

For citation: Larionova M. (2020) Saving the SDGs? Strengthening Partnership for Achieving SDGs in the Post-Covid-19 Digital World. International Organisations Research Journal, vol. 15, no 4, pp. $163-188$ (in English). DOI: 10.17323/1996-7845-2020-04-08.

\section{Introduction}

While 2020 was intended to launch the Decade of Action to achieve the United Nations Sustainable Development Goals (SDGs) by the target date of 2030 [UN, n.d.], the unprecedented health, social and economic crises induced by the COVID-19 pandemic plunged the world into the worst global recession since the Great Depression [IMF, 2020a] and reversed progress on

${ }^{1}$ The editorial board received the article in October 2020.

${ }^{2}$ This research was carried out with the financial support of the Russian Foundation for Basic Research within the framework of a research project entitled "Evolution of Multilateral Development Cooperation Under the Auspices of the United Nations: From Development Decade to Sustainable Development Goals (SDGs)," project no 18-014-00008. 
the SDGs [WB, 2020a], jeopardizing their implementation [UN, 2020a]. The success of the SDGs depends on two big assumptions: sustained economic growth and globalization. Both are questioned by the triple crisis. Five years after their adoption, the very foundations on which the SDGs were built have shifted [Naidoo, Fisher, 2020]. As we move toward the end of 2020, there is a need not only to assess the impact of the COVID-19 pandemic on economic growth and sustainable development, but also to reflect on how to build up cooperation and partnerships for saving the SDGs. To this end, this article reviews the COVID-19 pandemic's impact on economic growth and sustainable development and reviews estimates of the crisis' toll on the implementation of the SDGs. It then looks at the key initiatives and policy recommendations to prevent the SDGs from becoming casualties of COVID-19 and its responses [Khan, 2020]. It concludes by outlining priorities for strengthening international cooperation on sustainable development.

\section{A Systemic Human Development Crisis ${ }^{3}$}

The pandemic affected the full spectrum of the SDGs [UN, 2020c] directly due to the health impact of the virus, through resulting crisis response and mitigation measures, and through its aggregate economic and social effects [UN, 2020d]. As the goals are tightly interlinked, the effects are interconnected, mutually reinforcing and difficult to assess. However, an assessment is vital for understanding the scale of the collapse and for planning actions for a long ascent [IMF, $2020 \mathrm{~b}$ ] to the 2030 targets.

In May 2020, the United Nations Industrial Development Organization (UNIDO) estimated that COVID-19 was driving a global poverty ${ }^{4}$ rate change of $0.7 \%-(8.6-8.2 \%)-$ (7.8-8.1\%) - pushing 49 million people into extreme poverty in 2020 [UN, 2020e, p. 60]. In October, the World Bank estimated the addition of a staggering 88-115 million people, affecting between $9.1 \%$ and $9.4 \%$ of the world's population in 2020 , with the number of people newly living in extreme poverty to reach as many as 150 million by 2021 [WB, 2020a]. This assessment is a bit more optimistic than the April projection made by Andy Sumner, Chris Hoy and Eduardo Ortiz-Juarez forecasting a reversal of approximately a decade in the world's progress toward reducing poverty and an increase "in comparison to the status quo in 2018, by between $85-135$ million under a 5 per cent contraction" [2020, pp. 5-6]. The impact will be long-lasting. According to Homi Kharas' calculations, by 2030 the poverty numbers will be higher than the baseline by 60 million people [2020]. Rising inequality disproportionally affects the most vulnerable.

Even before COVID-19 broke out progress toward SDG target 2.1 (ensuring access to safe, nutritious and sufficient food for all people all year round) and target 2.2 (eradicating all forms of malnutrition) was insufficient. The situation in countries struck by conflict, natural disaster and economic crises is particularly acute. The United Nations Office for the Coordination of Humanitarian Affairs Projections warned of a rise in the number of people facing acute food insecurity from the pre-COVID-19 level of 149 million to 270 million by the end of the year [UN, 2020c]. Preliminary projections suggest that the COVID-19 pandemic may add an additional 83- 132 million people to the ranks of the undernourished in 2020 (based on a global economic growth drop ranging from 4.9-10\%) [UN, 2020f]. Food insecurity and malnutrition have a direct bearing on the health and well-being of people and further aggravate the risks of premature mortality.

\footnotetext{
${ }^{3}$ For references see UN [2020b, p. 4].

${ }^{4}$ Defined as living on less than $\$ 1.90$ a day.
} 
By the end of October, the COVID-19 pandemic had affected more than 44 million people and taken more than a million lives [WHO, n. d., a]. The pandemic undermined the capacity of health systems to provide essential services and medicines for all. At least two million preventable deaths could occur as a result of disrupted healthcare and resource diversion without appropriate mitigation [UN, 2020c, p. 5]. Disruption of vaccination programmes, regular check-ups and treatment of chronic diseases would "likely lead to numerous deaths, many of them avoidable. For example, in high-burden countries, it is estimated that over the coming five years deaths due to tuberculosis, HIV, and malaria will increase by 20, 10, and 36 percent, respectively" [WB, 2020b, p. 64]. The precarious state of health systems coupled with schools and university closures will result in a long-lasting human capital loss.

Learning disruptions, which have affected more than 1.5 billion students, will have longterm consequences. Erosion of skills is likely to cause a decline in income, productivity and gross domestic product (GDP). According to the Human Capital Index 2020 Update, this lost schooling may "translate to a yearly loss of over US\$872 in 2011 USD PPP, reaching a loss of US\$16,000 in lifetime earnings in present value terms assuming a 45-year work life" [WB, $2020 \mathrm{~b}$, p. 71$]$. The average GDP could be $1.5 \%$ lower on average for the remainder of the century compared to the forecast made before the pandemic [Schleicher, 2020, p. 4]. It is estimated that the COVID-19 crisis will increase the financing gap for reaching SDG 4 (quality education) in low- and lower-middle-income countries by up to one third on top of a staggering $\$ 148$ billion annual gap before the COVID-19 eruption [UN, 2020g, p. 7]. The school disruptions will exacerbate inequalities between and within countries, as the hysteresis induced by school closures may be more prevalent among students from less privileged backgrounds [OECD, 2020a]. Girls graduating from high school "are more likely to skip college during recessions because of the lower observed returns to education and because the cost of more schooling increases" [WB, 2020b, p. 94].

The pandemic is deepening pre-existing gender inequalities [UN, 2020h] as women are more likely to be informally employed or to work in industries most immediately affected by COVID-19 such as travel, tourism, retail, accommodation services, food and beverage service, and garment manufacturing [OECD, 2020b, pp. 7-8]. This translates into loss of income, inability to be self-supporting, and insecurity. Simultaneously, women are at the forefront of the battle against COVID-19 as they make up around $85 \%$ of nurses and midwives in the 104 countries for which data are available [Boniol et al., 2020]. Women carry out more care work than men, and as COVID-19 increased this workload it also amplified related problems such as access to safe drinking water, adequate sanitation and hygiene and also to affordable and reliable energy services.

A quarter of the world's population lacks access to a reliable water supply. Unsafe hygiene practices compound COVID-19's effects on people's health. The pandemic heightened awareness of the extent and consequences of this access gap. And it could slow progress in meeting the water supply, sanitation and hygiene SDGs as revenue losses by local governments and water utilities affect their ability to make critical capital investments [Butler et al., 2020].

The pre-pandemic data, according to which 789 million people globally were without access to electricity and close to three billion were without access to clean cooking in 2018, indicated an urgent need to step-up efforts to reach SDG 7 [IEA et al., 2020]. Even greater efforts are required to meet the SDG 7 targets in the COVID-19 and post-COVID-19 world. Access to energy is vital to support health facilities currently lacking electricity while serving one billion people, to reduce high levels of air pollution from households without clean cooking solutions (thus facing increased risks from COVID-19 respiratory illnesses) and to support access to information through the Internet and mobile phones [UN, 2020i, p. 21]. While the investment 
required for the overall financing of SDG 7 is estimated at \$1.3-1.4 trillion per year [Ibid.], the pandemic's impact on energy systems is curbing investments [Turk, Kamiya, 2020]. Moreover, this estimate does not include the enhanced electricity requirements of the cold chains needed to fight COVID-19, noting that most of the vaccine candidates will require storage in a $-80^{\circ} \mathrm{C}$ cold chain [Sustainable Energy for All, 2020].

The COVID-19 pandemic and the resulting containment measures triggered a sharp downturn in the first half of the year. The International Monetary Fund (IMF) projected GDP contraction of $4.4 \%$ in 2020 [IMF, 2020a], which may be only the tip of the iceberg. Significant differences in the depth of impact across regions, countries, sectors and population groups aggravate inequality. The loss of 495 million full-time equivalent jobs leads to a decline in labour incomes by $10.7 \%$ or $\$ 3.5$ trillion [ILO, 2020, p. 1]. The rise of unemployment and the collapse of tourism [UNWTO, 2020], retail and hospitality industries dealt a heavy blow to the goal of promoting sustainable and inclusive economic growth and productive employment.

Global manufacturing output growth registered a sharp decline of $6.0 \%$ in the first quarter of 2020 and a world average drop of $8.4 \%$ is forecasted by UNIDO for 2020 [UN, 2020j, p. 10]. Due to the downfall in the manufacturing sector coupled with factory shutdowns, global foreign direct investment (FDI) is expected to shrink by up to $40 \%$ in 2020 from the 2019 value of $\$ 1.54$ trillion, and by another 5-10\% in 2021, with a slight recovery in 2022 and a possible rebound to the pre-pandemic level in 2022 [UN, 2020k]. The decrease will have implications for sustainable infrastructure and industrialization of developing countries. It could be partially offset by public investment in high quality digital and green infrastructure. However, domestic resource mobilization for investment into high-return infrastructure projects is constrained by the need to allocate significant funds to combat the pandemic, a decrease in fiscal revenues due to sluggish economic activity, falling tourism and commodity prices, as well as devaluation of national currencies and, accordingly, rising costs of servicing government debts, two thirds of which for low-income countries are denominated in dollars [OECD, 2020c, p. 10].

As the COVID-19 recession will result in a $6.2 \%$ decline in global per capita GDP, contractions in per capita GDP in more than $90 \%$ of economies, a higher proportion than about $85 \%$ of countries affected by the Great Depression of 1930-32 [WB, 2020c, p. 15], prospects for reducing inequality within and between countries are jeopardized. A 9.2\% decline in the volume of world merchandise trade for 2020 , followed by a very modest $7.2 \%$ rise in 2021 [WTO, 2020a] impairs prospects for reducing inequalities and increasing income [Cerdeiro, Komaro$\mathrm{mi}, 2017]$. Inequality in access to the Internet and numbers of households with computers [UN, 2020e] constrained opportunities for development and securing jobs through remote learning and employment. The COVID-19 recession impacts people's capabilities for development. The Human Development Index, adjusted for COVID-19, projects a steep decline in human development worldwide in 2020, "equivalent to erasing all the progress in human development of the past six years" [UN, 2020b, p. 6].

The pandemic affected all dimensions of city life - economic, social, cultural - further exacerbating existing inequalities, as the impact of COVID-19 is differentiated and highly correlated with poverty, household crowding, poor housing conditions and limited access to health care. Cities and areas with strong exposure to global value chains and tourism were also among the most strongly affected, with health losses amplified by revenue losses that limit the capabilities of the local budgets and authorities to provide social support for the population, deploy digital solutions and finance economic recovery measures [OECD, 2020d] as well as progress toward the targets of sustainable and resilient cities and settlements.

The impact of the pandemic on sustainable consumption and production patterns is not unequivocal. The short-term reduction in natural resources use due to reduced economic activ- 
ity and consumption is coupled with pressures to loosen regulations on the circular economy and postpone the adoption of new measures so as not to impose additional burdens on businesses [Sachs et al., 2020]. Rapid digitalization of business models, production and consumption - a positive result of social isolation [Leal Filho et al., 2020] - offers an opportunity to embed climate-positive behaviour by continued teleworking and related reduction in $\mathrm{CO} 2$ emissions [Hepburn et al., 2020, p. 15]. However, waste of medical and protective equipment is expected to rise. Around $75 \%$ of used masks 5 and other pandemic-related waste is expected to "end up in landfills, or floating in the seas." Potential consequences include not only environmental damage, but also "public health risks from infected used masks and uncontrolled incineration of masks, leading to the release of toxins in the environment, and to secondary transmission of diseases to humans" [UN, 2020y].

Thus the small and short-term positive effects on environment-related SDGs (goals 6, $7,13,14,15$ and 17$)^{6}$ are offset by increased waste and reduced financial resources. Moreover, $\mathrm{CO} 2$ emissions are expected to rebound with the economic recovery unless the rescue and recovery measures are green. So far, the assessments indicate "that $4 \%$ of policies are 'green,' with potential to reduce long-run GHG emissions, $4 \%$ are 'brown' and likely to increase net GHG emissions beyond the base case, and $92 \%$ are 'colourless,' meaning that they maintain the status quo" [Hepburn et al., pp. 5-6]. Relief for the oceans related to shipping, transport and tourism suspension is temporary and insufficient. Key fragility factors of marine pollution and overfishing persist [UN, 20201]. The targets for 2020 to effectively regulate harvesting and end overfishing, conserve at least $10 \%$ of coastal and marine areas, and to prohibit fisheries subsidies which contribute to overcapacity and overfishing were not achieved. ${ }^{7}$ The same is true for goal 15's 2020 targets of ensuring the conservation, restoration and sustainable use of terrestrial and inland freshwater ecosystems, sustainable management of all types of forests and prevention of the extinction of threatened species [UN, 2020m]. Implementation of the UN Strategy [UN, 2020n] for the Decade on Ecosystem Restoration 2021-30 [UN, 2020p] will require a political will, but also significant resources, which in the post-pandemic world are even scarcer than after the 2007-08 financial crisis.

The pandemic has seriously tested economies, societies and institutions: self-isolation - a test for the right of mobility; the concentration of medical resources on the fight against COVID-19 - a test for the right to other essential health services; school closures - a test for the right to education. Digital monitoring of citizens' movements - a test to human rights. Cancellation or postponement of elections - a test for democratic rights [UN, 2020q]. These challenges, coupled with the enhanced risks of social unrest and violence, undermine the world's ability to meet the targets of goal 16 [UN, 2020m, p. 17] on promoting peaceful and inclusive societies, access to justice for all and effective, accountable and inclusive institutions at all levels. Moreover the level of violence in countries with conflicts and humanitarian crises did not decrease [International Crisis Group, 2020] despite the UN secretary-general's 23 March appeal for ceasefire [UN Secretary-General, 2020]. Belated adoption of the ceasefire resolution became a test for the Security Council. ${ }^{8}$

The 4.4\% drop in global GDP [IMF, 2020a], the largest decline in GDP per capita in 75 years [WB, 2020c, p. 15], the $13 \%$ reduction in trade, ${ }^{9}$ the disruption of global value chains and

${ }^{5}$ UNCTAD estimates that global sales of masks will total some $\$ 166$ billion this year, up from around $\$ 800$ million in 2019.

${ }^{6}$ Globally, GHG emissions might fall by $4-7 \%$ in 2020 [UN DESA, 2020].

${ }^{7}$ The declaration's text has not been finalized. For the available version with tracked proposed changes, see UN [2020z].

${ }^{8}$ The UN Security Council adopted the resolution on 1 June 2020 [UN, 2020r].

${ }^{9}$ In an optimistic scenario (in a pessimistic scenario - 32\%) [WTO, 2020b]. 
the $40 \%$ decline in foreign direct investment flows ${ }^{10}$ challenge the goal of strengthening global partnership for sustainable development at a time when it is more important than ever. Indeed, all domestic resources are now mobilized for the urgent needs of fighting COVID-19 and its consequences, stabilization of revenue from tax of economic activities cannot be expected sooner than 2022, ${ }^{11}$ remittance flows to low- and middle-income countries are expected to decline by $7.2 \%$ to $\$ 508$ billion in 2020 with a further decline of $7.5 \%$ to $\$ 470$ billion in 2021 [WB, 2020d, p. 6], and inflows of external private finance to official development assistance (ODA)eligible countries in 2020 are expected to plunge by $\$ 700$ billion compared to 2019 levels. Despite the intent of the members of the Development Assistance Committee (DAC) to protect ODA levels [OECD, 2020e] the Organisation for Economic Co-operation and Development (OECD) calculates that if DAC members keep the same ODA to gross national income (GNI) ratios as in 2019, total ODA could decline by $\$ 11$ billion to $\$ 14$ billion, depending on a single- or double-hit recession scenario on member countries' GDP [Ahmad et al., 2020]. Increases in debt servicing costs reduce the available fiscal space. The G20 Debt Service Suspension Initiative covers only 73 of the world's poorest countries [WB, 2020g], does not include debt to private creditors, and so far only affects $3.65 \%$ of the total debt service cost of developing countries in 2020 [Fresnillo, 2020]. "With all sources of external private finance falling immediately, this presents an unprecedented pressure for developing economies, exceeding the post-2008 Global Financial Crisis experience by 60\%" [OECD, 2020c, p. 8].

Digital technologies could not be effectively deployed to counter the impact of COVID-19 on education, health and employment as the digital divide is still huge with only $19 \%$ of citizens in the least developed countries (LDCs) online in 2019 and $47 \%$ in developing countries [ITU, 2019]. A decline in exports is expected to deteriorate the situation, especially for the LDCs. Emerging markets' financial needs are also enormous. Estimated at $\$ 2.5$ trillion, they significantly exceed these countries' own reserves and domestic resources [IMF, 2020c]. As a result, developing countries and emerging market economies are unable to implement support measures needed to overcome the crisis and return to the growth trajectory on the same scale as developed countries. The scale of assistance received from multilateral institutions is incomparable with the $\$ 8$ trillion mobilized to overcome the crisis by the world's leading economies [Battersby et al., 2020]. Thus, the risks of deepening economic and social inequality not only within countries, but also between countries, significantly increase.

The recovery of progress on the SDGs will be a much longer and harder ascent than the road to economic recovery. Many initiatives are already being undertaken, mostly focusing on support to developing countries in their response to the pandemic and associated economic shocks. The UN system coordinates the work under the Strategic Preparedness and Response Plan, the Global Humanitarian Response Plan and the UN COVID-19 Response and Recovery Fund. Local assistance to countries and communities was deployed already in spring 2020. By October 2020, about $\$ 2.5$ of the $\$ 10$ billion needed was mobilized [UN, 2020s, pp. 9-10]. The G20 adopted the Action Plan on Supporting the Global Economy Through the COVID-19 Pandemic [G20, 2020a], pledged to provide financial support to the World Health Organization (WHO) Strategic Preparedness and Response Plan and immediate resources to the New Solidarity Fund to help fight the COVID-19 pandemic. The WHO's COVID-19 response strat-

10 FDI is expected to continue declining by $5-10 \%$ in 2021 and begin to recover only in 2022 [UN, 2020k].

${ }^{11}$ And even after return to the current level, revenues will not be sufficient, as out of 124 countries eligible for official development assistance with published data on tax revenue in 2017, more than one third (46) have had tax-to-GDP ratios below 15\%, which is a widely considered benchmark for effective state functioning and promotion of economic development. Almost two thirds of countries in this sample (79) had collected tax revenue below $20 \%$ of GDP [OECD, 2020c]. 
egy [WHO, 2020] serves as the basis for developing national response plans. But the WHO is fulfilling its role as a coordinator of the international community's efforts with a very tight budget, and by autumn its COVID-19 programme was only $80 \%$ resourced [WHO, n. d., b].

The IMF generated credit resources of $\$ 1$ trillion and by mid-October provided assistance worth of special drawing rights (SDR) 64 billion to 80 countries, mainly using emergency and precautionary lending tools [Gregory, Lin, Mühleisen, 2020]. The Fund could do more if it received approval for an additional SDR emission and allocation for alleviating the problems of developing countries experiencing foreign exchange reserves difficulties [Plant, 2020]. In the same period the World Bank Group provided finance for health systems support projects in 111 countries [Malpass, 2020] and pledged to make available $\$ 160$ billion over a 15 -month period [WB, 2020h], though a shortage of financial resources expected in 2021 may constrain its future activities [WB, 2020e, p. ix]. The multilateral development banks (MDBs) made a $\$ 230$ billion commitment to emerging and low-income countries as a response to the pandemic [G20, 2020b]. However, this is still only a fraction of what is needed [Kharas, Dooley, 2020]. Moreover, though new lending provides funds for temporary support, it is scaling up debt, further exacerbating the fundamental problem of debt sustainability. Rescue of the SDGs requires a coordinated and comprehensive approach.

\section{Priorities for Strengthening the Means of Implementation and Revitalizing Global Partnership for Sustainable Development}

Two priorities stand out: harnessing the benefits of digitalization for sustainable development and putting forward a new comprehensive debt relief initiative for SDGs which would provide for reallocation of released funds to SDGs related to poverty and inequality eradication, and health and education.

\section{Operationalizing Digitalization Components in the SDG Targets and Indicators}

In the five years since the SDGs were introduced, the world has leapfrogged in terms of digital transformation. Digital technologies and solutions, which have become a critical resource in the fight against COVID-19 and a factor of sustained economic activity during the pandemic, can be a vital resource for achieving SDGs. The UN Secretary-General's Road Map for digital cooperation put forward a set of actions to accelerate global digital cooperation to facilitate progress toward achieving the goals by 2030 [UN, 2020t]. Indeed, for digitalization to become a driver of inclusive growth and sustainable development, many obstacles need to be addressed, including the digital divide in Internet access, ${ }^{12}$ lack of digital public goods, ${ }^{13}$ data protection and privacy concerns, ${ }^{14}$ gaps in international coordination, cooperation and governance of artificial intelligence, ${ }^{15}$ cybersecurity and critical infrastructure protection challenges,

${ }^{12}$ Only $53.6 \%$ of the world's population currently uses the Internet, which means that the number of people without Internet access is about 3.6 billion. Least developed countries have the lowest access rate - only $19 \%$ of the population [ITU, 2019].

${ }^{13}$ Such goods can be defined as open source software, open data, artificial intelligence models, standards and content that comply with privacy regulations and other applicable international and national laws, standards and best practices, and that do not cause harm.

14 The potential cost of data privacy violations worldwide is estimated to exceed $\$ 5$ trillion by 2024 [Security Magazine, 2019].

${ }^{15}$ There are currently more than 160 sets of ethical principles and principles of management in the field of artificial intelligence around the world, adopted by specific organizations and countries or agreed at the international level. However, there is no common platform for bringing these separate initiatives together. 
and the diffuse and exclusive nature of digital cooperation architecture [UN, 2020v, p. 21]. This is an enormous agenda, which can be disaggregated into concrete targets and indicators to supplement the existing SDGs' list of targets.

The proposed additions to the targets do not constitute either an exhaustive list or an ultimate truth (Table 1). They are intended as a start for a possible discussion on how digitalization can be operationalized and integrated into the SDGs.

\section{Table 1. Proposed Additions to SDG Targets and Indicators}

\begin{tabular}{|c|c|}
\hline Goals and Targets & Indicators \\
\hline \multicolumn{2}{|l|}{ Goal 1. End poverty in all its forms everywhere } \\
\hline $\begin{array}{l}\text { Target } 1.4 \text { By } 2030 \text {, ensure that all men and women, in } \\
\text { particular the poor and the vulnerable, have equal rights to } \\
\text { economic resources, as well as access to basic services, own- } \\
\text { ership and control over land and other forms of property, } \\
\text { inheritance, natural resources, appropriate new technology } \\
\text { and financial services, including microfinance }\end{array}$ & $\begin{array}{l}\text { Indicator 1.4.1 Proportion of population living in house- } \\
\text { holds with access to basic services } \\
\text { To be supplemented by } \\
\text { 1.4.3 Proportion of population living in households with access } \\
\text { to internet and digital devices (computers) }\end{array}$ \\
\hline \multicolumn{2}{|c|}{ Goal 2. End hunger, achieve food security and improved nutrition and promote sustainable agriculture } \\
\hline $\begin{array}{l}\text { Target } 2.4 \text { By 2030, ensure sustainable food production } \\
\text { systems and implement resilient agricultural practices that } \\
\text { increase productivity and production, that help maintain } \\
\text { ecosystems, that strengthen capacity for adaptation to } \\
\text { climate change, extreme weather, drought, flooding and } \\
\text { other disasters and that progressively improve land and soil } \\
\text { quality }\end{array}$ & $\begin{array}{l}\text { Indicator 2.4.1 Proportion of agricultural area under pro- } \\
\text { ductive and sustainable agriculture } \\
\text { To be supplemented by } \\
\text { 2.4.2 Proportion of agricultural area under productive and } \\
\text { sustainable agriculture empowered and monitored by digital } \\
\text { technologies }\end{array}$ \\
\hline \multicolumn{2}{|c|}{ Goal 3. Ensure healthy lives and promote well-being for all at all ages } \\
\hline $\begin{array}{l}\text { Target 3.c Substantially increase health financing, develop- } \\
\text { ment of telemedicine } \\
\text { and the recruitment, development, training and retention of } \\
\text { the health workforce in developing countries, especially in } \\
\text { least developed countries and small island developing States } \\
\text { to be supplemented with } \\
\text { development of telemedicine }\end{array}$ & $\begin{array}{l}\text { Indicator 3.c.1 Health worker density and distribution } \\
\text { To be supplemented by } \\
\text { 3.c.2 Development and access to telemedicine }\end{array}$ \\
\hline \multicolumn{2}{|c|}{ Goal 4. Ensure inclusive and equitable quality education and promote lifelong learning opportunities for all } \\
\hline $\begin{array}{l}\text { Target 4.a Build and upgrade education facilities that are } \\
\text { child, disability and gender sensitive and provide safe, non- } \\
\text { violent, inclusive and effective learning environments for all } \\
\text { to be supplemented by } \\
\text { 4.d Significantly increase the number of households with ac- } \\
\text { cess to (a) the Internet for learning purposes; (b) computers for } \\
\text { learning purposes }\end{array}$ & $\begin{array}{l}\text { Indicator } 4 . d .1 \text { Proportion of households with access to (a) } \\
\text { the Internet for learning purposes; (b) computers for learning } \\
\text { purposes }\end{array}$ \\
\hline $\begin{array}{l}\text { Target 4.c By 2030, substantially increase the supply of } \\
\text { qualified teachers, including through international coopera- } \\
\text { tion for teacher training in developing countries, especially } \\
\text { least developed countries and small island developing States }\end{array}$ & $\begin{array}{l}\text { Indicator 4.c.1 Proportion of teachers in: (a) pre-primary; } \\
\text { (b) primary; (c) lower secondary; and (d) upper secondary } \\
\text { education who have received at least the minimum organ- } \\
\text { ized teacher training (e.g. pedagogical training) pre-service } \\
\text { or in-service required for teaching at the relevant level in a } \\
\text { given country } \\
\text { To be supplemented by } \\
\text { 4.e.1 Proportion of teachers with remote teaching skills }\end{array}$ \\
\hline
\end{tabular}




\begin{tabular}{|c|c|}
\hline Goals and Targets & Indicators \\
\hline \multicolumn{2}{|l|}{ Goal 5. Achieve gender equality and empower all women and girls } \\
\hline $\begin{array}{l}\text { Target 5.b Enhance the use of enabling technology, in } \\
\text { particular information and communications technology, to } \\
\text { promote the empowerment of women }\end{array}$ & $\begin{array}{l}\text { Indicator } 5 . \text { b. } 1 \text { Proportion of individuals who own a mobile } \\
\text { telephone, by sex } \\
\text { to be supplemented by } \\
\text { 5.b. } 2 \text { Proportion of individuals who own a computer and have } \\
\text { access to Internet, by sex }\end{array}$ \\
\hline \multicolumn{2}{|c|}{$\begin{array}{l}\text { Goal 8. Promote sustained, inclusive and sustainable economic growth, full and productive employment and decent work } \\
\text { for all }\end{array}$} \\
\hline $\begin{array}{l}\text { Add target } \\
8.11 \text { By 2030, devise and implement policies to promote remote } \\
\text { work and strengthen the capacity of employers and employees } \\
\text { to expand remote work models }\end{array}$ & $\begin{array}{l}\text { Add indicator } \\
\text { 8.11 Proportion of remote jobs in employment }\end{array}$ \\
\hline \multicolumn{2}{|c|}{ Goal 9. Build resilient infrastructure, promote inclusive and sustainable industrialization and foster innovation } \\
\hline $\begin{array}{l}\text { Target } 9.4 \text { By } 2030 \text {, upgrade infrastructure and retro- } \\
\text { fit industries to make them sustainable, with increased } \\
\text { resource-use efficiency and greater adoption of clean and } \\
\text { environmentally sound technologies and industrial pro- } \\
\text { cesses, with all countries taking action in accordance with } \\
\text { their respective capabilities }\end{array}$ & $\begin{array}{l}\text { Indicator 9.4.1 CO2 emission per unit of value added } \\
\text { To be supplemented by } \\
\text { 9.4.2 FDI into green infrastructure and high-quality digital } \\
\text { infrastructure }\end{array}$ \\
\hline \multicolumn{2}{|l|}{ Goal 10. Reduce inequality within and among countries } \\
\hline $\begin{array}{l}\text { Target 10.6 Ensure enhanced representation and voice } \\
\text { for developing countries in decision-making in global } \\
\text { international economic and financial institutions in order to } \\
\text { deliver more effective, credible, accountable and legitimate } \\
\text { institutions } \\
\text { To be supplemented by } \\
\text { 10.8 Build inclusive digital governance architecture }\end{array}$ & \\
\hline \multicolumn{2}{|c|}{ Goal 17. Strengthen the means of implementation and revitalize the Global Partnership for Sustainable Development } \\
\hline $\begin{array}{l}\text { Target } 17.4 \text { Assist developing countries in attaining long- } \\
\text { term debt sustainability through coordinated policies aimed } \\
\text { at fostering debt financing, debt relief and debt restructur- } \\
\text { ing, as appropriate, and address the external debt of highly } \\
\text { indebted poor countries to reduce debt distress }\end{array}$ & $\begin{array}{l}\text { Indicator 17.4.1 Debt service as a proportion of exports of } \\
\text { goods and services } \\
\text { To be supplemented by } \\
\text { 17.4.2 Debt relief as a proportion of total debt (as of the end } \\
\text { of 2020) } \\
\text { 17.4.3 Debt relief amounts allocated to poverty and inequality } \\
\text { eradication, health and education related SDGs }\end{array}$ \\
\hline
\end{tabular}

Source: [UN, 2017].

\section{A New G20-Led Comprehensive Debt Relief Initiative for SDGs}

The costs of anti-pandemic measures, the drop in revenues, currencies devaluations and increased indebtedness came on top of debt levels that were already historically high [Georgieva, Pazarbasioglu, Weeks-Brown, 2020], creating immediate risks to liquidity and solvency and long-term risks to sustainable development. The G20 Debt Service Suspension Initiative (DSSI) does not reduce debt, simply deferring it. The DSSI, which was estimated to amount to approximately $\$ 477$ billion in 2018 debt stock [Bolton et al, 2020], is projected to allow 46 participant countries to suspend payments for a total of USD 11.7 billion even after a 6-month extension [Munevar, 2020]. The G20 finance ministers and central bank governors acknowl- 
edged the problems with the private creditors' participation in the DSSI and recognized that the scale of the crisis may require debt treatments beyond the DSSI on a case-by-case basis [G20, 2020b]. However, this promise, as well as the G20 and Paris Club decision on a "Common Framework for Debt Treatments Beyond the DSSI" [Paris Club, 2020], published in November on the eve of the G20 summit [G20, 2020c], is limited in scope, conservative in approach and does not address debt sustainability and equitability.

The Framework will be implemented on the Paris Club's terms, including the establishment and successful completion of an IMF programme and a successful track record of compliance with the Club [Munevar, 2020]. The initiative does not include the multilateral financial institutions. The IMF and the WB defend their non-participation in suspension of debt service payments on the grounds that there is potential for a negative impact on their financial sustainability [WB, 2020f] as they need resources to support countries' responses to the pandemic [IMF, 2020d]. Neither the Joint IMF-WBG Staff Note: Implementation and Extension of the Debt Service Suspension Initiative [IMF, WBG, 2020] nor the IMF proposal on The International Architecture for Resolving Sovereign Debt Involving Private-Sector Creditors - Recent Developments, Challenges, and Reform Options [IMF, 2020e] even consider the option of suspending debt payments to the Bretton Woods institutions. European Network on Debt and Development calculations show that "in 2018, the World Bank alone held $\$ 103.73$ billion in debt owed by DSSI eligible countries. From May to December 2020 - the period in which, for now, the DSSI is applicable for bilateral creditors - the cancellation of payments to the World Bank would free up $\$ 2.46$ billion. This could grow to more than USD 4 billion of additional resources if the cancellation was extended for a full year into 2021" [Fresnillo, 2020, p. 11].

Private creditors, represented by the Institute of International Finance (IIF), stated their support of the DSSI and developed instruments to facilitate the process. However, the IIF Update of Progress shows that by mid-July no waiver [IIF, n.d.] had been granted [IIF, 2020a]. The debtor countries are reluctant to approach due to the risk of ratings downgrades and associated restriction of their ability to access finance in global capital markets. Again, even in case of suspension the payments will be deferred, added to the original amount and accrue interest [IIF, 2020b]. Thus the pressure would be delayed rather than resolved. All in all, in its current mode the DSSI is unlikely to succeed [Munevar, 2020]. Moreover, there are 68 countries not eligible to participate in the G20 DSSI, with estimated external public debt service amounts projected to reach $\$ 273.43$ billion in 2020 . They have very few options for addressing debt burdens except case-by-case, complex and lengthy negotiations with a myriad of external private creditors [Fresnillo, 2020, p. 18].

The UN secretary-general called for an across-the-board debt standstill for all developing countries that have no access to financial markets and cannot service their debt and for the amendment of structural deficiencies in the international debt architecture to prevent defaults leading to prolonged financial and economic crises [IMF, 2020g]. Indeed, a comprehensive debt relief initiative is needed. It should include at least three initial steps.

First, an agreement of the G20, Paris Club members and international financial institutions should be negotiated to suspend, at least for five years and possibly write off, the accumulated debt services amounts, with allocation of the released funds to poverty and inequality eradication. ${ }^{16}$ Arguments of international law that can be invoked to justify debt cancellations include: force majeure, state of necessity and fundamental change in circumstances [CADTM, 2020]. The relief target of half of $\$ 2.5$ trillion needed according to United Nations Conference on Trade and Development (UNCTAD) estimates [2020] would be justified by the precedent [UN, 2020w, p. 14]. Economically, with G20 fiscal and monetary actions amounting to

${ }^{16}$ In line with the request of the African Union [AU, 2020]. 
about $\$ 10$ trillion to support their economies, "writing off the USD 3 trillion debt of the 135 countries of the South, or $83 \%$ of the world's population, does not seem to be an insurmountable obstacle" [Rivié, 2020]. Participation of private creditors should be ensured, otherwise "resources freed up via the efforts of other creditors and new emergency financing provided to fight the impacts of COVID-19, will effectively be diverted to pay non-participating creditors" [Fresnillo, 2020, p. 30].

Second, to support borrower countries that decide to suspend payments to private creditors and reallocate saved funds to increase health spending in response to COVID-19, the G20 and IFIs should agree on a debt standstill mechanism for private sector creditors. Some proposals have already been put forward. Daniel Munevar and Grygoriy Pustovit argue that the IMF has a mechanism in place to impose debt standstills. Article VIII, Section 2 (b) of the IMF articles of agreement allows the IMF to render exchange contracts unenforceable in domestic courts of IMF member countries following specific criteria. An agreement on a broad and authoritative interpretation of the exchange contracts' terms to cover debt contracts by the IMF executive board is required for its application. This interpretation would allow the sovereign borrower to request invocation of defence based on Article VIII, Section 2 (b) if the creditor decides to initiate litigation to enforce their claims in a foreign court, including the U.S. and the UK. Apart from the possibility of using existing provisions without amending the articles of agreement, the mechanism's advantages include "uniformity and comparability of treatment of the private creditors on a global level and incentives and time for creditors and debtors to negotiate and find a solution representing the best collective interest" [Munevar, Pustovit, 2020]. However, the history of the issue's discussion in the IMF suggests that the negotiation may be difficult and may meet opposition from the U.S. and the UK.

Another option put forward by the Centre for Economic Policy Research envisages "that multilateral institutions such as the World Bank or other multilateral development banks create a central credit facility allowing countries requesting temporary relief to deposit their stayed interest payments to official and private creditors for use for emergency funding to fight the pandemic. Principal amortisations occurring during that period would also be deferred, so that all debt servicing would be postponed" [Bolton et al., 2020]. This proposal has the advantages of equal treatment of the borrower's individual creditors, verification of how saved funds are actually spent, possibility of deferring the principal payments, relative flexibility and expediency. At the same time there may be little appetite for setting up a web of central credit facilities with potential expansion of the IFIs' bureaucracy. Whichever mechanism is adopted it will need the strong and cohesive support of the G20.

Third, the G20, the UN and financial institutions should explore the establishment of a mechanism under UN auspices which would support sovereign debt cancellation and restructuring, taking into consideration both the immediate threats and the requirements of implementing the sustainable development goals. Proposals to set up an autonomous international organization [UN, 2020w] may be viewed as unrealistic and idealistic. But cautious diplomatic formulas calling for comprehensive actions on debt will not resolve the problem. Fora, analysis and reports should be followed up by a high-level substantive and dedicated process. The UN Economic and Social Council (ECOSOC) Forum on Financing for Development follow-up (FfD Forum) track does not have either the capacity or political leadership ${ }^{17}$ to launch the process. However, the UN Secretary-general could put forward the initiative to G20 leaders. The G20 leaders' support and a mandate to the G20 Development Working Group to engage

${ }^{17}$ The complacency and lack of ambition of the summary by the president of the Economic and Social Council of the forum on financing for development follow-up (New York, 23 April 2019 and 2 June 2020) are striking [UN, 2020x]. 
with the UN and other international institutions on the elaboration of a concrete proposal for a debt relief and sustainability mechanism might become an important step toward debt sustainability. It would confirm the G20 commitment "to contribute to global efforts to implement the 2030 Agenda, including the Sustainable Development Goals (SDGs) and the Addis Ababa Action Agenda on Financing for Development (AAAA)" as stated in the G20 Action Plan on the 2030 Agenda for Sustainable Development adopted in Hangzhou [G20, 2016] and reiterated in Hamburg. Most importantly, it would provide a chance to develop a pragmatic and innovative solution to the systemic risk of unsustainable debt accumulation, preventing potential future crises.

\section{Conclusion}

The confluence of crises caused by the COVID-19 pandemic set back progress on sustainable development goals and jeopardized implementation of the 2030 Agenda. The triple shock became a major test to the Global Partnership for Sustainable Development. Human losses are exacerbated by a significant reduction of people's capabilities for development, resulting in a decline in human development worldwide equivalent to erasing six years of progress. Contraction of GDP, trade, employment and investment undermine foundations for growth and development.

International institutions have undertaken initiatives to support developing countries in their response to the pandemic and associated economic shocks. Understandably, these actions mostly focus on immediate risks rather than their long-term impacts, recovery and "building back better" to deliver the SDGs by 2030 . Moreover, the IFIs' lending is scaling up an already unsustainable debt burden. The G20 Debt Service Suspension Initiative defers payments but does not reduce debt. Importantly, it does not include payments to multilateral and private creditors and leaves the 68 countries not eligible for participation without support. Put together, the costs of anti-pandemic measures, the drop in revenues and growing debt on top of historically high pre-crisis debt levels create immediate solvency risks and long-term threats to sustainable development.

Rescue of the SDGs is not feasible without innovative and comprehensive solutions. At least two priorities should be considered. To harness the benefits of digitalization for sustainable development, key components of digitalization should be incorporated into the SDGs as concrete targets and indicators. The list proposed in this article is intended as a start for a possible discussion. To address the systemic risk of unsustainable debt accumulation and prevent potential future crises, a comprehensive debt relief initiative is needed. The G20-led process would include as a first step negotiating an agreement of the G20, Paris Club members and international financial institutions to suspend, at least for five years with a possible write off, the accumulated debt services amounts, an agreement with the IFIs on a debt standstill mechanism for private sector creditors and consultations on the establishment of a mechanism under UN auspices which would support sovereign debt cancellation and restructuring. To re-energize the human development process, the initiative should provide for the condition that the released funds will be allocated to SDGs on poverty and inequality eradication, and health and education.

The G20 Comprehensive Debt Sustainability Initiative for SDGs will help strengthen means of the SDGs' implementation and revitalize the Global Partnership for Sustainable Development. It will demonstrate that the G20 remains both a crisis manager and a premier forum of economic cooperation committed to the goal of strong, sustainable, balanced and inclusive growth. 


\section{References}

Ahmad Y., Bosch E., Carey E., Mc Donnell I. (2020) Six decades pf ODA: insights and outlook in the COVID-19 crisis. Available at: https://www.oecd-ilibrary.org/sites/2dcf1367-en/1/3/1/1/index.html?itemId=/content/ publication/2dcf1367-en\&_csp_=177392f5df53d89c9678d0628e39a2c2\&itemIGO=oecd\&itemContentType $=$ book (accessed 02 November 2020).

AU. (2020) Communiqué of the Meeting of the Bureau of the Assembly Heads of State \& Government With Chairpersons of the Regional Economic Communities (RECS). Available at: https://au.int/ar/node/38688 (accessed 03 November 2020).

Battersby B., Lam R., Ture E. (2020) Tracking the \$9 Trillion Global Fiscal Support to Fight COVID-19. Available at: https://blogs.imf.org/2020/05/20/tracking-the-9-trillion-global-fiscal-support-to-fight-covid-19/ (accessed 03 November 2020).

Boniol M., McIsaac M., Xu L., Wuliji T., Diallo K., Campbell J. (2019) Gender equity in the health workforce: Analysis of 104 countries. Health Workforce Working paper 1. Available at: https://apps.who.int/iris/bitstream/ handle/10665/311314/WHO-HIS-HWF-Gender-WP1-2019.1-eng.pdf?sequen (accessed 02 November 2020).

Bolton P., Buchheit L., Gouurinchas P.-O., Gulati M., Hsieh C.-T., Panizza U., di Mauro B.W. (2020) Born Out of Necessity: A debt Standstill for COVID-19. CEPR Policy Insight No. 103 April 2020. Available at: https://cepr.org/sites/default/files/policy_insights/PolicyInsight103.pdf (accessed 03 November 2020).

Butler G., Pilotto R.G., Hong Y., Mutambatsere E. (2020) The Impact of COVID-19 on the Water and Sanitation Sector. Available at: https://www.ifc.org/wps/wcm/connect/126b1a18-23d9-46f3-beb7-047c20885bf6/ The+Impact+of+COVID_Water\%26Sanitation_final_web.pdf?MOD=AJPERES\&CVID=ncaG-hA (accessed 02 November 2020).

CADTM. (2020a) The CADTM denounces the G20's measures on debt. Available at: https://www.cadtm.org/ The-CADTM-denounces-the-G20-s-measures-on-debt (accessed 03 November 2020).

CADTM. (2020b) 6 months after the official announcements of debt cancellation for the countries of the South: Where do we stand? Available at: http://www.cadtm.org/6-months-after-the-official-announcements-of-debtcancellation-for-the (accessed 03 November 2020).

Cerdeiro D., Komaromi A. (2017) The Effect of Trade on Income and Inequality: A Cross-Sectional Approach. Available at: https://www.imf.org/ /media/Files/Publications/CR/2017/cr1766-ap-2. ashx\#: : text $=$ Countries\%20with\%20higher\%20trade\%20penness,standards\%20and\%20lower\%20income $\% 20$ inequality.\&text $=$ Since $\% 20$ these $\% 20$ policies $\% 20$ are $\% 20$ likely,omitted $\% 20$ from $\% 20$ the $\% 20$ na\%C3\%AFve\%20approach. (accessed 02 November 2020).

Filho L.W., Brandli L.L., Salvia A.L., Rayman-Bacchus L., Platje J. (2020) COVID-19 and the UN Sustainable Development Goals: Threat to Solidarity or an Opportunity? Sustainability, 12 (13) 5343. DOI: https:// doi.org/10.3390/su12135343

Fresnillo I. (2020) Shadow report on the limitations of the G20 Debt Service Suspension Initiative: Draining out the Titanic with a bucket? Available at: https://www.eurodad.org/g20_dssi_shadow_report (accessed 03 November 2020).

Georgieva K. (2020a) The Long Ascent: Overcoming the Crisis and Building a More Resilient Economy. Available at: https://www.imf.org/en/News/Articles/2020/10/06/sp100620-the-long-ascent-overcoming-the-crisisand-building-a-more-resilient-economy (accessed 02 November 2020).

Georgieva K. (2020b) Transcript of Press Briefing by Kristina Georgieva following a Conference Call of the International monetary and Financial Committee. Available at: https://www.imf.org/en/News/Articles/2020/03/27/ tr032720-transcript-press-briefing-kristalina-georgieva-following-imfc-conference-call (accessed 03 November 2020).

Georgieva K., Pazarbasioglu C., Weeks-Brown R. (2020) Reform of the International Debt Architecture is Urgently Needed. Available at: https://blogs.imf.org/2020/10/01/reform-of-the-international-debt-architectureis-urgently-needed/ (accessed 03 November 2020).

Gregory R., Lin H., Mühleisen M. (2020) IMF Lending During the Pandemic and Beyond. Available at: https:// blogs.imf.org/2020/09/17/imf-lending-during-the-pandemic-and-beyond/ (accessed 03 November 2020). 
G20. (2020a) G20 Finance Ministers and Central Bank Governors Meeting Communique 15 April 2020. Available at: https://g20.org/en/media/Documents/G20_FMCBG_Communiqu\%C3\%A9_EN\%20(2).pdf (accessed 03 November 2020).

G20. (2020b) G20 Finance Ministers and Central Bank Governors Meeting Communique 14 October 2020. Available at: https://g20.org/en/media/Documents/FMCBG\%20Communiqu\%C3\%A9 English_14October2020_700pm.pdf (accessed 03 November 2020).

G20. (2016) G20 Action Plan on the 2030 Agenda for Sustainable Development. Available at: https://www.un.org/ development/desa/financing/sites/www.un.org.development.desa.financing/files/2020-06/20-07663_Summary\%202020\%20FFD\%20Forum_0.pdf (accessed 03 November 2020).

G20, Paris Club. (2020) Template waiver letter agreement for debtor countries participating in the G20/Paris Club Debt Service Suspension Initiative (official sector) ("G20/Paris Club DSSI"). Available at: https://www.iif.com/ Portals/0/Files/content/Regulatory/G20\%20DSSI-\%20Template\%20Waiver.pdf (accessed 03 November 2020).

Hepburn C., O’Callaghan B., Stern N., Stiglitz J., Zengheils D. (2020) Will COVID-19 fiscal recovery packages accelerate or retard progress on climate change? Available at: https://www.smithschool.ox.ac.uk/publications/ wpapers/workingpaper20-02.pdf (accessed 02 November 2020).

IEA, IRENA, UN, World Bank, WHO. (2020) The Energy Progress Report 2020. Available at: https://trackingsdg7.esmap.org/data/files/download-documents/tracking_sdg_7_2020-full_report_-_web_0.pdf (accessed 02 November 2020).

IMF. (2020a) World Economic Outlook, October 2020: A Long and Difficult Ascent. Available at: https://www. imf.org/en/Publications/WEO/Issues/2020/09/30/world-economic-outlook-october-2020\#Growth\%20 Projections\%20Table (accessed 02 November 2020).

IMF. (2020b) The International Architecture for Resolving Sovereign Debt Involving Private-Sector Creditors - Recent Development, Challenges, And Reform Options. Available at: https://www.imf.org/en/Publications/ Policy-Papers/Issues/2020/09/30/The-International-Architecture-for-Resolving-Sovereign-Debt-InvolvingPrivate-Sector-49796 (accessed 03 November 2020).

IMF, World Bank. (2020) Joint IMF-WBF Staff Note: Implementation and Extension of the Debt Service Suspension Initiative. Available at: https://www.devcommittee.org/sites/dc/files/download/Documents/2020-10/ Final\%20DC2020-0007\%20DSSI.pdf (accessed 03 November 2020).

IIF. (2020a) Progress Update on Private Sector Engagement in the G20 Debt Service Suspension Initiative (DSSI). Available at: https://www.iif.com/Portals/0/Files/content/Regulatory/Progress\%20Update\%20to\%20G20 vf.pdf (accessed 03 November 2020).

IIF. (2020b) Terms of Reference for Voluntary Private sector Participation in the G20 / Paris Club Debt Service Suspension Initiative ("DSSI"). Available at: https://www.iif.com/Portals/0/Files/content/Regulatory/Voluntary\%20Private\%20Sector\%20Terms\%20of\%20Reference\%20for\%20DSSI_vf.pdf (accessed 03 November 2020).

ILO. (2020) ILO Monitor: COVID-19 and the world of work. Sixth ed. Available at: https://www.ilo.org/wcmsp5/groups/public/---dgreports/---dcomm/documents/briefingnote/wcms_755910.pdf (accessed 02 November 2020).

ITU. (2019) Measuring digital development. Facts and figures 2019. Available at: https://www.itu.int/en/ITU-D/ Statistics/Documents/facts/FactsFigures2019.pdf (accessed 03 November 2020).

Khan A. (2020) Four ways to prevent the Sustainable Development Goals becoming a casualty of Covid-19 responses. Available at: https://www.odi.org/blogs/17169-four-ways-prevent-sustainable-development-goals-becoming-casualty-covid-19-responses (accessed 02 November 2020).

Kharas H. (2020) The Impact of COVID-19 on global extreme poverty. Available at: https://www.brookings. edu/blog/future-development/2020/10/21/the-impact-of-covid-19-on-global-extreme-poverty/ (accessed 02 November 2020).

Kharas H., Dooley M. (2020) Sustainable development finance proposals for the global COVID-19 response. Available at: https://www.brookings.edu/wp-content/uploads/2020/08/Development-Financing-Options Final.pdf (accessed 03 November 2020). 
Malpass D. (2020) COVID-19 Response, new research on human capital, and looking ahead to our Annual Meeting. Available at: https://blogs.worldbank.org/voices/september-21-2020-covid-19-response-new-researchhuman-capital-and-looking-ahead-our-annual (accessed 03 November 2020).

Munevar D. (2020) The G20 "Common Framework for Debt Treatment beyond the DSSI": Is it bound to fail? Part 1. Available at: https://www.eurodad.org/the_g20_common_framework_for_debt_treatments_beyond_the_dssi_is_it_bound_to_fail\#: :text $=$ The $\% 20 \mathrm{G} 20 \% \overline{2} 0$ recently $\% 20$ announced $\overline{\%} 20$ the ,of $\% 20$ the $\% 20$ Covid\%2D19\%20pandemic. (accessed 03 November 2020).

Munevar D., Pustovit G. (2020) Back to the Future: A sovereign debt standstill mechanism. Available at: https:// d3n8a8pro7vhmx.cloudfront.net/eurodad/pages/544/attachments/original/1590696076/Back_to_the_Future.pdf? 1590696076 (accessed 03 November 2020).

Naidoo R. (2020) Reset Sustainable Development Goals for a pandemic world. Available at: https://www.nature. com/articles/d41586-020-01999-x (accessed 03 November 2020).

OECD. (2020a) Education and COVID-19: Focusing on the long-term impact of school closures. Available at: https:// read.oecd-ilibrary.org/view/?ref=135_135187-1piyg9kc7w\&title=Education-and-COVID-19-Focusing-onthe-long-term-impact-of-school-closures (accessed 02 November 2020).

OECD. (2020b) Women at the core of the fight against COVID-19 crisis. Available at: https://read.oecd-ilibrary. org/view/?ref=127_127000-awfnqj80me\&title=Women-at-the-core-of-the-fight-against-COVID-19-crisis (accessed 02 November 2020).

OECD. (2020c) The impact of the coronavirus (COVID-19) crisis on developmentfinance. Available at: https://read. oecd-ilibrary.org/view/?ref=134_134569-xn1goli113\&title=The-impact-of-the-coronavirus-(COVID-19)crisis-on-development-finance (accessed 02 November 2020).

OECD. (2020d) The territorial impact of COVID-19: Managing the crisis across levels of government. Available at: https://read.oecd-ilibrary.org/view/?ref=128_128287-5agkkojaaa\&title=The-territorial-impact-of-covid19-managing-the-crisis-across-levels-of-government (accessed 02 November 2020).

Plant M. (2020) Making the INFs Special Drawing Rights Work for COVID-19 Economic Relief. Available at: https://www.cgdev.org/publication/making-imfs-special-drawing-rights-work-covid-19-economic-relief (accessed 03 November 2020).

Sachs J., Schmidt-Trraub G., Kroll C., Lafortune G., Fuller G., Woelm F. (2020) The Sustainable Development Goals and COVID-19. Available at: https://s3.amazonaws.com/sustainabledevelopment.report/2020/2020 sustainable_development_report.pdf (accessed 02 November 2020).

Sumner A., Hoy C., Ortiz-Juarez E. (2020) Estimates of the impact of COVID-19 on global poverty. Available at: https://www.wider.unu.edu/sites/default/files/Publications/Working-paper/PDF/wp2020-43.pdf (accessed 02 November 2020).

Schleicher A. (2020) The Impact of COVID-19 on Education. Insights from Education at a Glance 2020. Available at: https://www.oecd.org/education/the-impact-of-covid-19-on-education-insights-education-ata-glance-2020.pdf (accessed 02 November 2020).

Turk D., Kamiya G. (2020) The impact of the COVID-19 crisis on clean energy progress. Available at: https:// www.iea.org/articles/the-impact-of-the-covid-19-crisis-on-clean-energy-progress (accessed 02 November 2020).

UN. (2020a) Progress towards the Sustainable Development Goals. Available at: https://undocs.org/en/E/2020/57 (accessed 02 November 2020).

UN. (2020b) COVID-19 and Human Development: Assessing the Crisis, Envisioning the Recovery. Available at: http://hdr.undp.org/sites/default/files/covid-19_and_human_development_0.pdf (accessed 02 November 2020).

UN. (2020c) Global Humanitarian Response Plan. Available at: https://www.unocha.org/sites/unocha/files/ GHRP-COVID19_July_update.pdf (accessed 02 November 2020).

UN. (2020d) UN/DESA Policy Brief \#78: Achieving the SDGs through the COVID-19 response and recovery. Available at: https://www.un.org/development/desa/dpad/publication/un-desa-policy-brief-78-achievingthe-sdgs-through-the-covid-19-response-and-recovery/ (accessed 02 November 2020). 
UN. (2020e) How COVID-19 is changing the world: a statistical perspective. Available at: https://stat.unido.org/ content/publications/how-covid-19-is-changing-the-world\%253a-a-statistical-perspective;jsessionid=8B4E FADD7C574FD0D1D5B03149D4C5A3 (accessed 02 November 2020).

UN. (2020f) The state of food security and nutrition in the world. Available at: http://www.fao.org/3/ca9692en/ CA9692EN.pdf (accessed 02 November 2020).

UN. (2020g) Policy Brief: Education during COVID-19 and beyond. Available at: https://www.un.org/development/desa/dspd/wp-content/uploads/sites/22/2020/08/sg_policy_brief_covid-19_and_education_august_2020.pdf (accessed 02 November 2020).

UN. (2020h) Policy Brief: The Impact of COVID-19 on Women. Available at: https://www.un.org/sites/un2. un.org/files/policy_brief_on_covid_impact_on_women_9_apr_2020_updated.pdf (accessed 02 November 2020).

UN. (2020i) Accelerating SDG7 Achievement in the Time of COVID-19. Available at: https://sustainabledevelopment.un.org/content/documents/26235UNFINALFINAL.pdf (accessed 02 November 2020).

UN. (2020j) World Manufacturing Production (Report). Available at: https://stat.unido.org/content/publications/world-manufacturing-production;jsessionid=8B4EFADD7C574FD0D1D5B03149D4C5A3 (accessed 02 November 2020).

UN. (2020k) World Investment Report 2020. Available at: https://unctad.org/system/files/official-document/ wir2020_en.pdf (accessed 02 November 2020).

UN. (20201) Changing Sails: Accelerating Regional Actions for Sustainable Oceans in Asia and the Pacific. Available at: https://www.unescap.org/sites/default/files/publications/CS76\%20Theme\%20Study.pdf (accessed 02 November 2020).

UN. (2020m) Progress towards the Sustainable Development Goals. Available at: https:/undocs.org/ en/E/2020/57 (accessed 02 November 2020).

UN. (2020n) The United Nations Decade on Ecosystem Restoration. Available at: https://wedocs.unep.org/bitstream/handle/20.500.11822/31813/ERDStrat.pdf?sequence=1\&isAllowed=y (accessed 02 November 2020).

UN. (2020p) The UN Decade on Ecosystem Restoration 2021-2030. Available at: https://wedocs.unep.org/bitstream/handle/20.500.11822/30919/UNDecade.pdf?sequence=11 (accessed 02 November 2020).

UN. (2020q) COVID-19 and Human Rights. We are all in this together. Available at: https://wedocs.unep.org/ bitstream/handle/20.500.11822/30919/UNDecade.pdf?sequence=11 (accessed 02 November 2020).

UN. (2020r) Resolution 2532(2020). Available at: https://undocs.org/en/S/RES/2532(2020) (accessed 02 November 2020).

UN. (2020s) United Nations Comprehensive Response to COVID-19. Available at: https://www.un.org/sites/un2. un.org/files/un-comprehensive-response-to-covid-19.pdf (accessed 03 November 2020).

UN. (2020t) Road map for digital cooperation: implementation of the recommendations of the High-level Panel on Digital Cooperation. Available at: https://undocs.org/en/A/74/821 (accessed 03 November 2020).

UN. (2020v) Roadmap for Digital Cooperation. Available at: https://www.un.org/en/content/digital-cooperation-roadmap/assets/pdf/Roadmap_for_Digital_Cooperation_EN.pdf (accessed 03 November 2020).

UN. (2020w) From the Great Lockdown to the Great Meltdown: Developing Country Debt in the Time of Covid-19. Available at: https://unctad.org/system/files/official-document/gdsinf2020d3_en.pdf (accessed 03 November 2020).

UN. (2020x) Summary by the President of the Economic and Social Council of the forum on financing for development follow-up (New York, 23 April 2019 and 2 June 2020). Available at: https://www.un.org/development/desa/ financing/sites/www.un.org.development.desa.financing/files/2020-06/20-07663_Summary\%202020\%20 FFD\%20Forum_0.pdf (accessed 03 November 2020).

UN. (2017) Revised list of global Sustainable Development Goal indicators. Available at: https://unstats.un.org/ sdgs/indicators/Official\%20Revised\%20List\%20of\%20global\%20SDG\%20indicators.pdf (accessed 03 November 2020).

World Bank. (2020a) Poverty and Shared Prosperity 2020. Available at: https://openknowledge.worldbank.org/ bitstream/handle/10986/34496/9781464816024.pdf (accessed 02 November 2020). 
World Bank. (2020b) The Human Capital Index 2020 Update: Human Capital in the Time of COVID-19. Available at: https://openknowledge.worldbank.org/handle/10986/34432?cid=ECR_E_NewsletterWeekly_EN_ EXT\&deliveryName $=$ DM78486 (accessed 02 November 2020).

World Bank. (2020c) Global Outlook. Pandemic, Recession: The Global Economy in Crisis. Available at: https:// openknowledge.worldbank.org/bitstream/handle/10986/33748/211553-Ch01.pdf (accessed 02 November 2020).

World Bank. (2020d) Phase II. COVID-19 Crisis Through a Migration Lens. Available at: https://www.knomad. org/sites/default/files/2020-10/Migration\%20\%26\%20Development\%20Brief\%2033.pdf (accessed 02 November 2020).

World Bank. (2020e) World Bank Group COVID-19 Crisis Response Approach Paper. Available at: http:// documents1.worldbank.org/curated/en/136631594937150795/pdf/World-Bank-Group-COVID-19-CrisisResponse-Approach-Paper-Saving-Lives-Scaling-up-Impact-and-Getting-Back-on-Track.pdf (accessed 03 November 2020).

World Bank. (2020f) Protecting the Poorest Countries: Role of the Multilteral Development Banks in Times of Crisis. Available at: http://pubdocs.worldbank.org/en/976541595021399817/DSSI-Explanatory-Note.pdf (accessed 03 November 2020).

WHO. (2020) 2019 Novel Coronavirus (2019 - nCoV): Strategic Preparedness and Response Plan. Available at: https://www.who.int/publications/i/item/strategic-preparedness-and-response-plan-for-the-new-coronavirus (accessed 03 November 2020). 